\title{
LANGUAGE LEARNER AUTONOMY: THE BELIEFS OF ENGLISH LANGUAGE STUDENTS
}

\author{
Istanti Hermagustiana, Dian Anggriyani \\ Universitas Mulawarman Samarinda, Indonesia \\ (istantihermagustiana@fkip.unmul.ac.id)
}

Received: $26^{\text {th }}$ August 2019; Revised: $14^{\text {th }}$ November 2019; Accepted: $28^{\text {th }}$ December 2019

\begin{abstract}
This study aims at investigating: (1) levels of autonomous learning from three groups of students with different periods of study, (2) EFL students' beliefs towards learner autonomy and their lecturers' roles in promoting learner autonomy. The participants of this study were three groups of EFL students at English Department in their second, fourth, and sixth semesters. The data were obtained through questionnaire surveying Autonomous Learning Scale to find out the students' levels of autonomy and interview to figure out their beliefs about learner autonomy and the roles of lecturers to promote autonomous learning. This study revealed that all group of students were classified as being in the mediate level of autonomy. From the interviews conducted to nine participants representing each group, it was found that to become autonomous, learners need to develop the ability to evaluate their own learning. Moreover, out-of-class activities were believed to enhance learner autonomy since the activities will provide students with self-responsibility to manage the tasks. Last, in terms of the lecturers' roles in the classroom, most participants perceived that the lecturers still had a dominant role in controlling teaching and learning, particularly in the classroom context. This dominant role eventually led students to become less autonomous circumstances, both inside and outside classrooms.
\end{abstract}

Key Words: learner autonomy; students' beliefs; autonomous learning; EFL context

\section{ABSTRAK}

Penelitian ini bertujuan untuk mengetahui: (1) tingkat pembelajaran mandiri dari tiga kelompok mahasiswa Bahasa Inggris dengan periode studi yang berbeda, dan (2) keyakinan mahasiswa Bahasa Inggris terhadap pembelajaran mandiri dan peran para dosen pengajar dalam mendukung pembelajaran mandiri di kelas. Para partisipan penelitian ini adalah tiga kelompok mahasiswa yang belajar di Jurusan Pendidikan Bahasa Inggris di semester kedua, keempat, dan keenam. Data diperoleh melalui angket survei Autonomous Learning Scale untuk mengetahui tingkat pembelajaran mandiri mahasiswa dan melalui wawancara untuk mengetahui pandangan mereka tentang pembelajaran mandiri dan peran dosen pengajar untuk mempromosikan pembelajaran mandiri. Hasil yang didapat dari penelitian ini adalah bahwa semua kelompok siswa dari tiga periode studi yang berbeda diklasifikasikan dalam pembelajaran mandiri tingkat menengah. Dari wawancara yang dilakukan kepada sembilan peserta yang mewakili setiap kelompok, diketahui bahwa untuk menjadi mandiri, mahasiswa perlu mengembangkan kemampuan untuk mengevaluasi pembelajaran mereka sendiri. Selain itu, kegiatan di luar kelas diyakini dapat meningkatkan pembelajaran mandiri karena kegiatan tersebut akan mengembangkan tanggung jawab dalam mengelola tugas. Begitu pun dalam hal peran dosen di ruang kelas, sebagian besar mahasiswa merasa bahwa dosen masih memiliki peran dominan dalam mengendalikan proses belajar mengajar, terutama di dalam kelas. Peran dominan dosen ini pada akhirnya menyebabkan mahasiswa menjadi kurang mandiri baik di dalam maupun di luar kelas.

Kata Kunci: pelajar mandiri; keyakinan siswa; pembelajaran mandiri; Konteks EFL

How to Cite: Hermagustiana, I., Anggriyani, D. (2019). Language Learner Autonomy: The Beliefs of English Language Students. IJEE (Indonesian Journal of English Education), 6(2), 133-142. doi:10.15408/ijee.v6i2.15467 


\section{INTRODUCTION}

In the field of foreign language learning and teaching, the importance of supporting students in becoming more autonomous has become one of the most prominent themes. The majority of theorists, researchers, and methodologists have been stressing the need for making learners capable of taking responsibility for their own learning (Cakici, 2017; Chan, 2016; Henri, Morrell, \& Scott, 2018; Liu, 2011; Mutlu \& Eroz-Tuga, 2013; Nguyen, 2014; Rungwaraphong, 2012; Salehi, Ebrahimi, Sattar, \& Shojaee, 2015). In addition, autonomy is currently viewed as a prerequisite for success in language learning.

Learner autonomy has been a major area of interest in foreign language teaching for some 30 years. According to Borg and Al-Busaidi (2012), it has been claimed that learner autonomy improves the quality of language learning, promotes democratic societies, prepares individuals for life-long learning, and allows learners to make the best use of learning opportunities in and out of the classroom. Holec (1981), who is considered as the father of autonomous learning, defines it as the ability to control one's learning. Likewise, Little (1991) asserts that "autonomous learners are cast in a new perspective, have a capacity for detachment, critical reflection, and decision making, take independent actions and are expected to assume greater responsibility for and take charge of their own learning" (p. 4). Holec (1981) and Little's (1991) definitions of learner autonomy are strongly echoed by Littlewood (1996) who defines an autonomous learner as someone who has an independent capacity to make and carry out the choices which govern his or her actions.

A number of research on learner autonomy from EFL context show that despite EFL students are considered to be passive and less autonomous to some extent, some others are found to understand the concept of learner autonomy, thus have responsibility and ability in their own learning as part of autonomous learning (Balcikanli, 2010; Gamble, Aliponga, Koshiyama, Yoshida, Ando, \& Wilkins, 2011; Karababa, Eker, \& Arik, 2010; Szocs \& College, 2017; Sakai, Takagi, \& Chu, 2010; Xhaferi \& Xhaferi, 2011). However, students' dependence on teachers in the classroom can still be found in EFL classroom setting. Based on the researchers' experience in their classroom practice, English students tend to follow what the lecturers' instructions. In terms of assessment, the lecturers show their power over the classroom by carrying out written tests merely in the middle and at the end of 
the semester. This often turns out a problem to achieve student-centered approach (Aslan \& Reigeluth, 2015)

Based on the phenomena above, this study is going to investigate university students' beliefs about the importance of learner autonomy and lecturers' roles in promoting autonomous learning in EFL context as well as the factors which constrain the students from being autonomous. Therefore, this study seeks to find out: (1) What is the level of students' autonomous learning from three groups of EFL students with different lengths of study at a university? and (2) What beliefs do the EFL students hold about learner autonomy and their lecturers' roles to promote learner autonomy?

\section{METHOD}

This is a mixed method study which focuses on both quantitative and qualitative data. The study started with a quantitative survey, which was administered to 60 English students. The second phase was qualitative design where the researchers selected a few participants identified from the survey result to be interviewees.

Three groups of young adult students were purposively selected based on their length of study or batch: students at second, fourth, and sixth semesters. Their ages range from 18 to 20 years old. They learn not only English skills and knowledge but also teaching skills in order to teach English to primary and secondary school students. Each group was represented by 20 students. As a consequence, there were 60 participants getting involved in this study. Learner autonomy questionnaires developed by Macaskill and Taylor (2010) were distributed to 60 participants. After the quantitative phase, nine participants who were categorized as the high, middle, and low autonomous learners based on the result of the questionnaire were selected to be part of Focus Group Discussion (FGD).

The researchers utilized two research instruments to collect the data, namely Autonomous Learning Scale (ALS) and an FGD. The ALS consists of 21 questions with respondents rating themselves on a 5-point Likert scale. For analysis, the responses are always weighted such that a higher value corresponds to greater autonomy. Subsequently, some interview questions were asked to nine participants with the highest level of learner autonomy form each batch identified from the survey result. An FGD was employed since it was useful to obtain detailed information about both personal and group beliefs about 
learner autonomy and to provide a broader range of information concerning the focused topic. Moreover, it was used to save time.

The researchers analyzed the results gained through questionnaires and interviews. For the results of the questionnaire, the researchers calculated the results of the questionnaire by using five-point Likert scale. The students were required to choose among the options for the statements: Strongly Agree, Agree, Neutral, Disagree, Strongly Disagree with the conversion scores: 5, 4, 3, 2, 1 respectively. The students with high scores were considered having high level of autonomous learning, and those with low scores were regarded as having low level of autonomous learning as shown from the table below.

Table 1. Learner autonomy level

\begin{tabular}{lll}
\hline Category & & Score range \\
\hline $\begin{array}{l}\text { High level of } \\
\text { autonomy }\end{array}$ & $84-105$ \\
$\begin{array}{l}\text { Mediate level of } \\
\text { autonomy }\end{array}$ & $43-83$ \\
$\begin{array}{l}\text { Low level of } \\
\text { autonomy }\end{array}$ & $21-42$ \\
\hline
\end{tabular}

The analysis of the interview results began by transcribing the students' interviews. The researcher made some codes based on the students' interview transcripts.
Following this, similar codes of information were applied to develop a small number of categories which were used to build main themes.

\section{RESULTS AND DISCUSSION}

\section{Results}

Based on the findings from the questionnaire, all of the students from three groups are in the mediate level of learner autonomy. It was shown from the mean score of each group. The overall scores of learner autonomy revealed from Group 1 (second semester), Group 2 (fourth semester), and Group 3 (sixth semester) are 72, 75, and 72 respectively. When converted into the table of learner autonomy level, it shows that all groups belong to the mediate level of learner autonomy. In other words, the students are both autonomous and less autonomous in some ways.

Based on the questionnaire results, their autonomous learning behavior is cultivated in a number of situations, such as: when they meet an assessment deadline for their work; when they have to find their own resources for learning, such as through internet; and when they have responsibility for their learning experiences. On the other hand, the participants' learning autonomy is hampered in the following 
situations: when they have to arrange their time management, particularly to study and review the learned materials; when they meet a challenge in the classroom; and when they have to stimulate their interest in language learning.

\section{Student Beliefs about Learner Autonomy}

Most of the participants demonstrated different understandings towards learner autonomy concept. Most of the participants were not quite aware of being autonomous in their learning activities. However, they understood that being autonomous in learning resulted in the students' liberty to select how they want to acquire knowledge. Moreover, they affirmed that learner autonomy would benefit the students with high confidence level since those students confidently learned English even though they were not guided by teachers. They also argued that to become autonomous, the students needed to get some chances to develop their ability in evaluating their own learning. It means that having been able to judge their own strengths and weaknesses, the students would notice other materials that they still need to enhance and materials they have already mastered. This would lead to students' independence in selecting as well as analyzing the material content appropriate for their level of English. In addition to developing learner autonomy through students' evaluation skills, motivation is another aspect the students need to own to develop learner autonomy.

Furthermore, they believed that students with autonomy in learning could be categorized as effective learners. All in, they all believed that learner autonomy means students' freedom about how they manage their learning. In other words, they are free to choose any materials and activities they want to have. All of the participants agreed that out-of-class activities assigned by the lecturers would stimulate their learning autonomy. In addition, libraries are also considered a good place to enhance their autonomy while learning English. This is because they can search any kind materials they don't have, particularly when they have some assignments from the lecturers. Additionally, self-confidence and motivation play important roles to promote learner autonomy since confident as well as motivated students would not be reluctant and reckless to be responsible for their own learning. They understand that learning means responsibility. Therefore, the development of learner autonomy can be achieved through those aspects. 


\section{The Roles of Lecturers in the}

\section{Classroom}

Most of the participants revealed that they still considered their lecturers played an important role in classroom practices. From several aspects of learning activities, the lecturers dominated some of the responsibilities, such as cultivating their learning interests, determining learning objectives of the course and learning materials simultaneously. In spite of the dominant roles the lecturers have, both lecturers and students are responsible for the following learning and teaching process in the classroom, such as monitoring learning progress in and outside the classrooms, selecting appropriate learning activities for classroom practice, determining time allotment, and evaluating students' work and performance.

From the interview, it was found out that the participants had responsibility for managing their own learning progress outside the classroom. Additionally, the other two participants stated that it was their responsibility to manage their own learning inside the classroom. In other words, they believed that their own learning progress was their own responsibility, not the lecturers'.

\section{Discussion}

The results of this present study is aligned with some previous studies which demonstrate that EFL learners, particularly Asian have a mediate level of autonomous learning (Nguyen, 2014; Rungwaraphong, 2012). In order to be more autonomous, learners need to be aware of language, language use and language learning while also conscious of affective factors that influence their relationship with language and language learning (McDevitt, 1997). Only when learners are explicitly aware of the language learning process and the roles they play in it, may it be well for them to fully involve themselves in the language learning. Then, learners need to be aware that they should share the responsibility with their teachers. They must realize that a lot of responsibility and knowledge will be transferred from the teacher to them (Jacobs \& Farrell, 2001).

When the students are being autonomous, it does not necessarily mean that they do everything (Benson \& Voller, 1997; Littlewood, 1996), but rather, that situation is supposed to lead students to be interdependence. Teachers may provide cooperative learning in providing students chances to be responsible for their own learning (Liu, 2011). Therefore, teachers have a job to manage cooperative group 
activities in the classroom such as group discussion, pair work, open questions, etc. By doing so, learner autonomy can be promoted along with the participation, self-confidence, and motivation of the students.

In terms of teacher's roles, this present study reveals that the decision to promote learner autonomy comes usually from the teacher, and the success of attempts to empower learners to become actively involved in their learning depends to a large extent on the teacher's ability to redefine their roles. This is in line with the previous studies which shows the dominant roles of teachers towards their students (Borg \& Al Busaidi, 2012; Cakici, 2017). The traditional EFL teaching model in Indonesia is a transmission model emphasizing the importance of teachers and their functions. Teachers serve as transmitters of cultural heritage, knowledge and skills. They impart knowledge for students to absorb. Students should show their respect for their teachers by obeying and cooperating with their teachers. They should listen to lectures attentively and follow their teachers' instructions in class. The relationship between the teacher and students is based on students' respect for the teacher and his knowledge as an authority (Jacobs \& Farrell, 2001)
As a result of the paradigm shift towards learner-centered education, efforts should be made to teach students how to learn and encourage them to be more autonomous. Teachers should help them form a good habit of learning in the autonomous learning process, rather than impart knowledge to students. The shift of responsibility from teachers to learners in language teaching process does not necessarily mean a complete rejection of teachers and normal classroom teaching is redundant. Instead, the teacher will find his role becomes more varied rather than curtailed, strengthened rather than weakened (not in terms of authority but in terms of competence) and much greater demands will be made on his creativity than on his highly developed knowledge of teaching techniques (Holec, 1981). The teacher still should be the guide of the whole autonomous learning process. Learners need a great deal of guidance and feedback from the teacher in order to learn to organize their work on their own. In classroom situations the teachers in autonomous learning functions as facilitators, helpers or counselors. They are more of a resource person or consultant than an authority; they are facilitators of classroom activities who concerned with their own sensitivity to the diversities of learner beliefs about language learning 
and their individual differences in learning styles; above all they are to help learners to depend on themselves to learn. More exactly speaking, the teacher will help learners plan and carry out their independent language learning by means of need analysis (both learning and language needs), objective setting (both short- and longterm, achievable), work planning, selecting materials and organizing interactions; help learners evaluate themselves (assessing initial proficiency, monitoring progress, and self- and peer-assessment); help learners acquire the skills and knowledge needed to implement learner autonomy. No matter how well the language teachers have performed in fulfilling their roles, it is students themselves who comprise the determining factor in their ultimate learning outcomes, especially in the learner-centered teaching context. Therefore, language learning requires autonomy on the part of learners.

\section{CONCLUSION AND SUGGESTIONS}

EFL students in this study believed that learner autonomy took place mostly outside the classroom when they were assigned to do out-of-class activities which supported their in-class activities. Moreover, even though outof-class activities are believed to enhance students' autonomous learning, teachers/lecturers have an important role in guiding the students to be independent learners.

Teachers/lecturers are perceived to have a dominant role in the classroom; therefore, it is quite hard for the students to reach $100 \%$ autonomy in their English learning. However, some of the participants argued that they had full responsibility for monitoring their learning progress either inside or outside the classroom. In addition, both students and lecturers also shared responsibilities in the process of teaching and learning including determining learning materials and activities.

This study focuses on students' level of learning autonomy and their beliefs about learner autonomy as well as their perceptions on teacher's roles in the classroom. Some pedagogical implications came up to provide EFL teachers important insights for better classroom practices. First, due to the dominant roles of teachers/lecturers in the classroom, teachers could provide more out-of-class activities for students in order to enhance learner autonomy. Second, by making the students get used to being autonomous, teachers would indirectly teach them about the concept of learner autonomy since their conceptual perspectives about learner 
autonomy would support their practical experience in carrying out autonomous learning. Third, teachers can start reducing their responsibilities in managing students' learning progress since it is very important to get the students involved in decision making process in the classroom. Fourth, the use of cooperative learning may help EFL students enhance their learning autonomy since that method focuses more on student-centered rather than teacher-centered.

\section{REFERENCES}

Aslan, S. and Reigeluth, C. M. (2015). Examining the challenges of learnercentered education. The Phi Delta Kappan 97(4): 63-68.

Balcikanli, C. (2010). Learner autonomy in language learning: Student teachers' beliefs. Australian Journal of Teacher Education 35(01): 90-103.

Benson, P. and Voller, P. (1997). Introduction: Autonomy and independence in language learning. In P. Benson \& P.Voller (Eds.), Autonomy and independence in language learning (pp. 112). London: Longman.

Borg, S. \& Al-Busaidi, S. (2012). Learner Autonomy: English Language Teachers' Beliefs and Practices. ELT Research Paper 12(07): 2-34.

Cakici, D. (2017). An investigation of learner autonomy in Turkish EFL context. International Journal of Higher Education 6(2): 89-99.

Chan, H. W. (2016). Popular culture, English out-of-class activities, and learner autonomy among highly proficient secondary students in Hong Kong.
Universal Journal of Educational Research 4(8): 1918-1923.

Gamble, C., Aliponga, J., Koshiyama, Y., Yoshida, K., Ando, S., and Wilkins, M. (2011). Examining learner autonomy dimensions: Students' perceptions of their responsibility and ability. In JALT Conference Proceedings 263-272.

Henri, D. C., Morrell, L.J., and Scott, G. W. (2018). Student perceptions of their autonomy at university. Higher Education 75: 507-516.

Holec, H. (1981). Autonomy in foreign language learning. Oxford: Oxford University Press.

Jacobs, G. M., and Farrell, T. S. C. (2001). Paradigm shift: Understanding and implementing change in second language education. TESL-EJ 5(1).

Karababa, Z. C., Eker, D. N., and Arik, R. S. (2010). Despcriptive study of learner's level of autonomy: Voices from the Turkish language classes. Procedia Social and Behavioral Sciences 9: 16921698.

Little, D. (1991). Learner Autonomy. I: Definition, issues and problems. Dublin: Authentik.

Littlewood, W. (1996). Autonomy: an anatomy and framework. System 24(4): 427-435.

Littlewood,W. (1999). Defining and developing learner autonomy in East Asian contexts. Applied Linguistics 20(1): 71-94.

Liu, Y. (2011). A study on learners' beliefs about learner autonomy in English language learning. Education and Educational Technology 108: 725-732.

Macaskill, A., and Taylor, E. (2010). The development of a brief measure of learner autonomy in university students. Studies in Higher Education 35(3): 351-359. 
McDevitt, B. (1997). Learner autonomy and the need for learner training. Language Learning Journal 16: 34-39.

Mutlu, A., and Eroz-Tuga, B. (2013). The role of computer-asisted language learning (CALL) in promoting learner autonomy. Eurasian Journal of Educational Research 51:107-122.

Nguyen, T. N. (2014). Learner autonomy in language learning: Teachers' beliefs. PhD Dissertation, Queensland Unversity of Technology.

Rungwaraphong, P. (2012). The promotion of learner autonomy in Thailand tertiary education: Lecturers' perspectives and practices. $\mathrm{PhD}$ Dissertation, Victoria University.

Sakai, A., Takagi, A., and Chu, M. (2010). Promoting learner autonomy: Student perceptions of responsibilities in a language classroom in East Asia. Educational Perspectives 43(1/2): 12-27.
Salehi, H., Ebrahimi, M., Sattar, S., and Shojaee, M. (2015). Relationship between EFL learners' autonomy and speaking strategies they use in conversation classes. Advances in Language and Literary Studies 6(2): 37-43.

Szocs, K., and College, E. J. (2017). Teachers' and learners' beliefs about language learning autonomy and its implications in the classroom: A mixed method study. Journal of Applied Language Studies 11(2): 125-145.

Xhaferi, B. And Xhaferi, G. (2011). Developing learner autonomy in higher education in Macedonia. Procedia Social and Behavioral Sciences 11: 150-154. 